\title{
The Analysis Of Opinions About Teaching Profession On Twitter Through Text Mining
}

\author{
Seda Gündüzalp, ${ }^{a}$ Gönül Şener ${ }^{b}$ \\ aMunzur University, Turkey, sedagunduzalp@munzur.edu.tr, https://orcid.org/0000-0003-3546-5644 \\ ${ }^{b}$ Munzur University, Countrygonulsener@munzur.edu.tr, https://orcid.org/0000-0003-3212-7703
}

\begin{abstract}
Billions of data in social media have provided a very influential platform for researchers to make research on data analysis. In the digital age, it has become essential for conducting an analysis of written things in social media in which the individuals express easily themselves without any pressure and for studying big data. It has been known that there are shared subjects on the education like almost every subject on the Twitter platform. Accordingly, it is often shared about many issues relating to education. The purpose of the present study is to analyze shared ideas on the 'teaching' profession through this program, which has become popular recently. It was observed that the shared tweets were often related to the current problems about education and Twitter was used as a platform by the individuals to explain their problems. It was a considerable finding that most of the tweets focused on contracted teaching, the positions of appointment, public personnel selection exam and the system of exams, issues about assignation, paid to teach and interview issues that there are a great number of reaction tweets against negative evaluation about vacations of teacher and particularly, against the situations just like damaging the sanctity the teaching profession and these tweets take place in the category the most retweeted. With this research, it is suggested to make analyses on social media platforms with other data mining techniques on the same subject or different subjects, to analyze the shares of institutions and to examine the sharing of the Ministry of National Education
\end{abstract}

Keywords: Teaching profession, Twitter, text mining, association rule mining

\section{Introduction}

Nowadays, along with the increasing popularity of smartphones in the digital age, it is the fact that the person and the associations have frequently used these platforms, which are called social media, reached by the internet and the information and feelings are shared verbally and visually for different purposes. The individuals could follow the country and the world's agenda by social media and they could share their personal ideas and feelings on a subject. With the increase of power and domain of social media, institutions have started to commonly use this platform for the areas such as information and notice. Today, social media has a great role in modern life allowing the users to share their feelings and thoughts without any limits. Social media is a platform accessed by the internet, which supports collaboration, building community, participation and sharing (Junco, Heiberger \& Loken, 2011). Social media has changed the paradigms of information dissemination. The probability that the users become interesting and content former rather than becoming only an information receiver has appeared through social media (Sanchez, Hermoso, In iguez, Pan o-Pardo, Bandres, Martinez, 2019). On analysis of the development of social media, it is clearly seen that Tom Truscott and Jim Ellis are the first researchers at the University of Duke in 1979 who developed Usenet, which is a worldwide platform to allow internet users receive public messages. It is possible to utter that 'in 1998, the real social media period has started with a social networking system "Open Diary",' which Bruce and Susan Abelson gather online writers ( Kaplan \& Haenlein, 2010). With Web 2.0 technologies, a new concept is being used to define a new method, due to which the number of participative web sites has increased. Social media and new media period starting with the blogs has become a system in which billions of people in the world are often connected by the platforms such as Facebook, Twitter, 


\section{The Analysis Of Opinions About Teaching Profession On Twitter Through Text Mining}

Seda Gündüzalp \& Gönül Şener

Instagram and YouTube recently (Kaplan, 2017; Kaplan \& Haenlein, 2010). The individuals have continued to include this system ${ }^{1}$.

\section{Main text}

The people could share the daily idea, argue them and suggest new ideas in social media since social media provides cyber sharing and it has easy accessibility. Furthermore, the users could share several photos, videos, look for a job, even find a job and live the real world in the cyber world without getting tired. It is the reason why it has rapidly stood out and gained a new conceptual framework (Vural \& Bet, 2010). As one of the terms frequently used in daily life, the term 'social media' has newly been seen in the literature and turned into a controversial term. Several researchers put forward that media is itself social and the definition such as social media could not be suitable. They suggest that new media should be used. However, the frequent use of social media in both literature and daily language legitimate the term social media (Kaplan, 2017). Hence, the use of the term social media has been approved in the present study.

On being analysed by the number of users, Twitter is one of the top-ranking programs in social networking sites. Every user could convey their idea about each issue on the agenda by writing through Twitter. Having worldwide fame, Twitter was a microblog social networking site including the messages with just 140 characters when it was first used. It became widespread with the common use of the famous people, the presidents, newsman and each citizen and to have a possibility to the access to these people and to connect by sending short messages (Pourebrahim, Sultana, Thill \& Mohanty, 2018; Kaplan, 2017; Tang \& Hew 2017; Kaplan \& Haenlein, 2010). Nearly the sharing with 240 characters has been carried out since 2017.

One person with a smartphone, computer or internet network could post tweets throughout the world at any time. New mobile technologies that make twitters turn into a part of daily activities have continuously been adapted (Yakın \& Tinmaz, 2013). Used by different sections of society, such as a great number of authors, doctors, teachers and directors, twitter could be seen as an entertainment device or a tool in which every feeling and thought is shared. It is used as a platform in which an author has noticed his book, a teacher shared the activities in the classroom, nongovernmental organizations meet in a short time and organize, or an individual comments on a movie (Odabaş1 et al., 2012). Twitter has been seen as a professional and social network since individuals with the same domains meet on twitter (Bicen \& Cavus, 2012). The individuals require only an e-mail address for login to any account or set personal profiles directed by the system (Tang \& Hew, 2017). Users could subscribe with their names or nicknames. The first tweet (it means the messages on Twitter) was posted by the Twitter creator, Jack Dorsey on 21 March 2006 (https://blog.twitter.com/official/en_us/a/2011/numbers.html). Today, nearly 700 billion tweets have been posted by 126 million active users twice a day. Nearly 6000 tweets are shared every second. It equals to 350,000 tweets a minute, 500 million tweets a day, 2000 billion tweets a year ( Internet Live Stats, 2019). The purposes of Twitter could be shown as follows (Odabaşı et al., 2012):

- Form content and sharing information

- Communication and Social Connection

- To form a collaborative and participative setting

Twitter presents an easy device to spread the information and a strong device to collect information at the same time (Sanchez et al., 2019). Several studies regarding the use of Twitter as an instructive device and its effects on it have been conducted (McArthur \& Bostedo Conway, 2012; Bista, 2015; Lin et al., 2013; Luttrell, 2012; Vooren \& Bess, 2013; Aspden \& Thorpe, 2009; Wright, 2010; Kassens-Noor, 2012; Junco et al., 2011; Prestridge, 2014; Adams et al., 2018; Chawinga, 2016; Tur \& Marn, 2015; Tang \& Hew, 2017; Nagle, 2018; Biçen and Çavuş, 2012). In the present study, it was concluded that Twitter developed collaboration, reflective and critical thinking and encouraged the students creating information; besides, it helped informal learning and it would positively affect the attention and awareness of e-learning and increase the interaction (Aydin, 2014)

Billions of data in social media have provided a very influential platform for researchers to conduct research on data analysis. In the digital age, it has become essential for conducting an analysis of written things in social media in which the individuals express themselves easily without any pressure and for studying big data. It has been known that there are shared subjects on education like almost every subject on Twitter platform. Accordingly, it is often shared about many issues in education. The purpose of the present study is to analyze shared ideas on the 'teaching' profession through this program, which has become popular recently. In parallel with this purpose:

- Which one of them is the most retweeted tweet?

- Which one of them is the most liked tweet?

- Which words are collocated with tweets including the word of the teaching profession and how is the relationship between the collocated words and teaching profession?

\footnotetext{
${ }^{1}$ This study was partly presented at the 6th International Eurasian Educational Research Congress in Ankara, 19 June - 22 June, 2019
}

Research on Education and Media. Vol. 12, N. 1, Year 2020 - ISSN: 2037-0830 


\section{Structure}

\subsection{Research Design}

This study has been framed by phenomenology design evaluated in qualified phenomenology. It enables us to consider the phenomenon, which we could see but we could not have any detailed information about. Phenomenology enables us to conduct research on the phenomenon that realized not exactly understood (Yıldırım \& Şimşek, 2011).

\subsection{Research Sample}

The target population of the study consists of the whole users who shared their opinions about teaching profession on Twitter. Working group involves the users who shared about the subject between 20.05.2019 and 15.06.2019. Criterion sampling method was used since the date range is a criterion.

\subsection{Data Collection}

The research data was obtained through Twitter API. Primarily, permission were asked from the Twitter official website for the extraction of research data about research subjects on Twitter. Following the scrutiny of the authorities of Twitter, the key numbers of API, necessary for the extraction of data has been received, the unpaid versions of KNIME and NodeXL program were used as a tool.

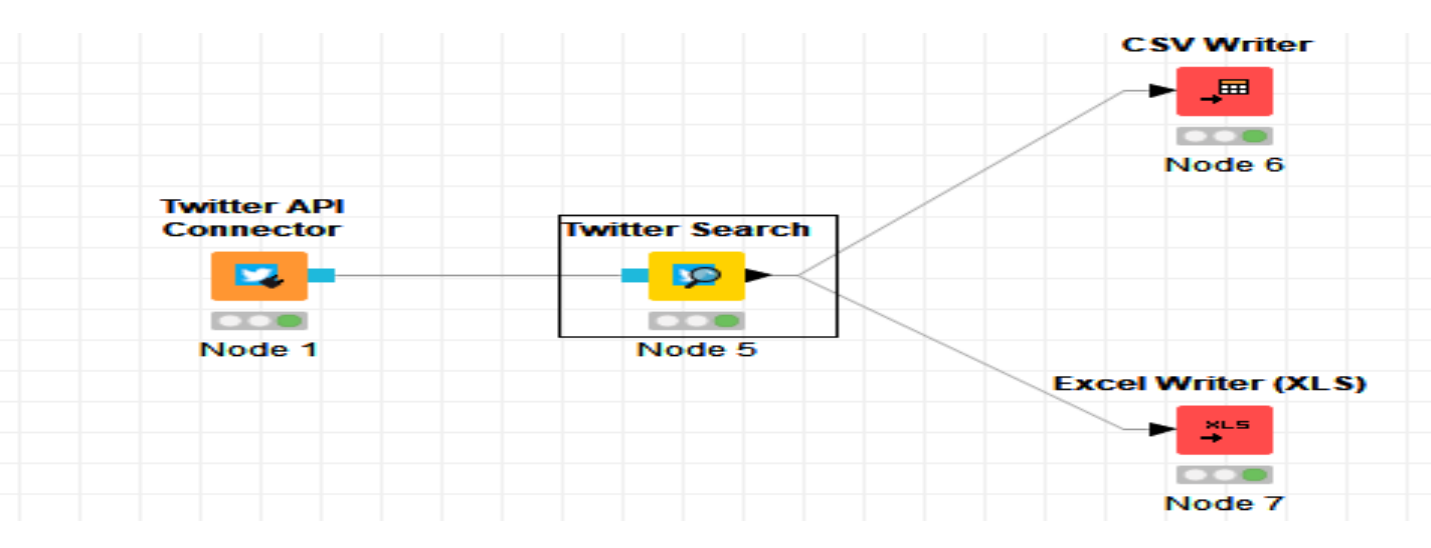

Figure 1. Data extraction process from Twitter

As seen in the figure, downloaded data by KNIME and NodeXL program were merged in an excel file. As there is the possibility of taking the same tweets in the programs, with the remove instruction, it was blocked that one tweet takes place more than one line. Totally, 35,718 tweets were obtained as data. Excel file is shown in Figure 2. 


\section{The Analysis Of Opinions About Teaching Profession On Twitter Through Text Mining}

Seda Gündüzalp \& Gönül Şener

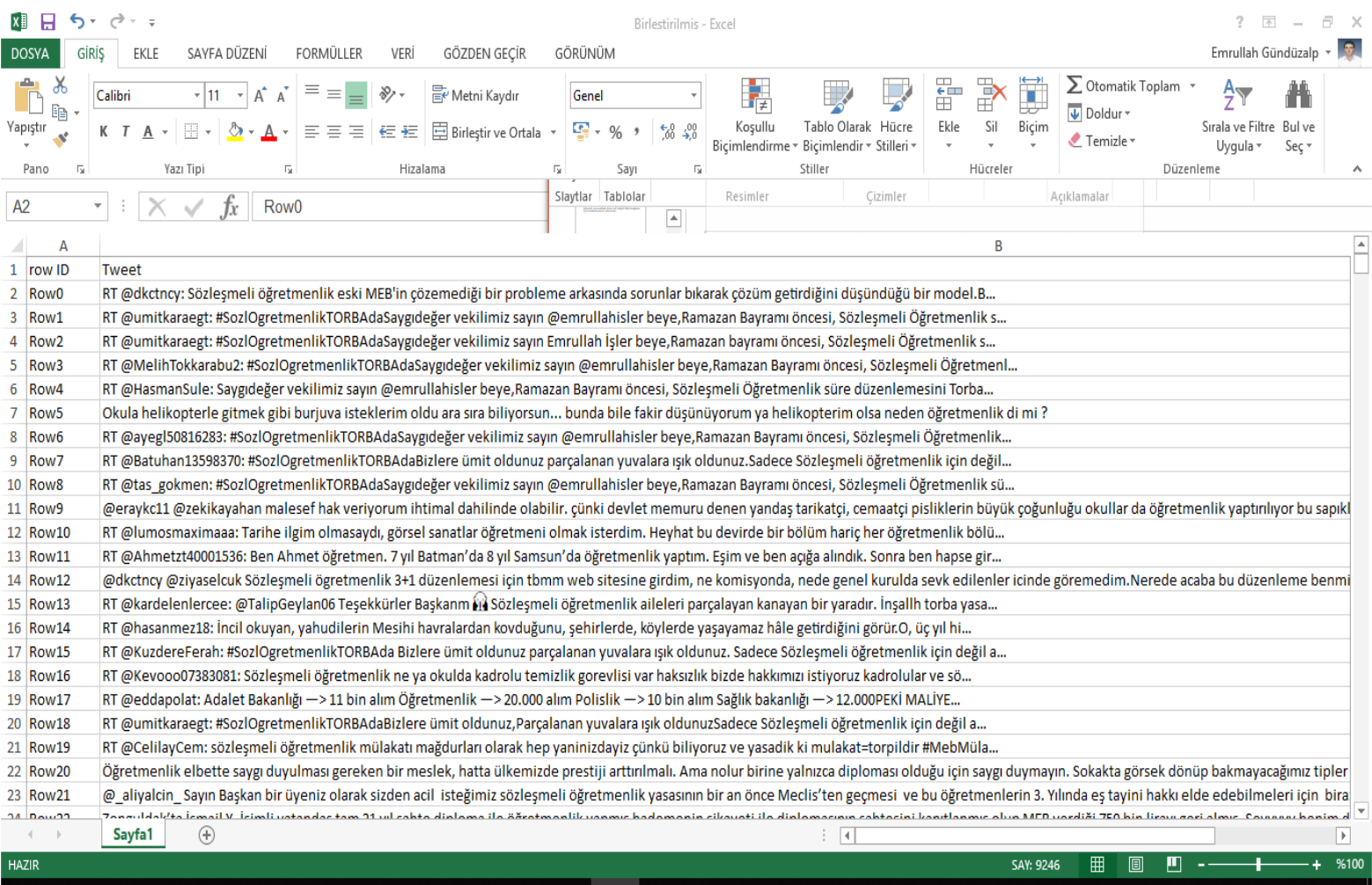

Figure 2. Data file

\subsection{Data Cleansing/Data Pre-Processing}

It was too difficult to analyze unprocessed social media data and it was observed that most of these consisted of poorly written words, abbreviations and jargon words that were only exclusive to social media and not used in daily language (Meral and Diri, 2014). Hence, the cleansing of extracted data was conducted. The purpose of cleansing data was to remove the wrong and the end data, and to convert it to a format that would not affect the analysis (Tuncer and Çetintaş, 2019). Data cleansing of this study is shown in Figure 3 and Figure 4.

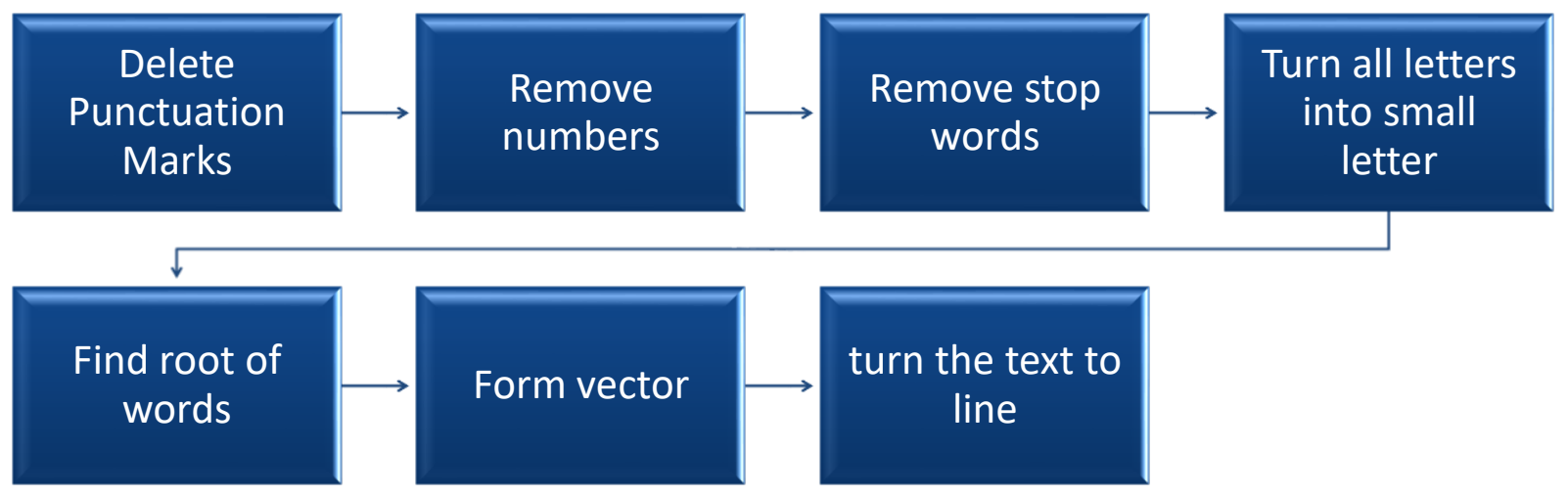

Figure 3. Data cleansing process 


\section{The Analysis Of Opinions About Teaching Profession On Twitter Through Text Mining}

Seda Gündüzalp \& Gönül Şener

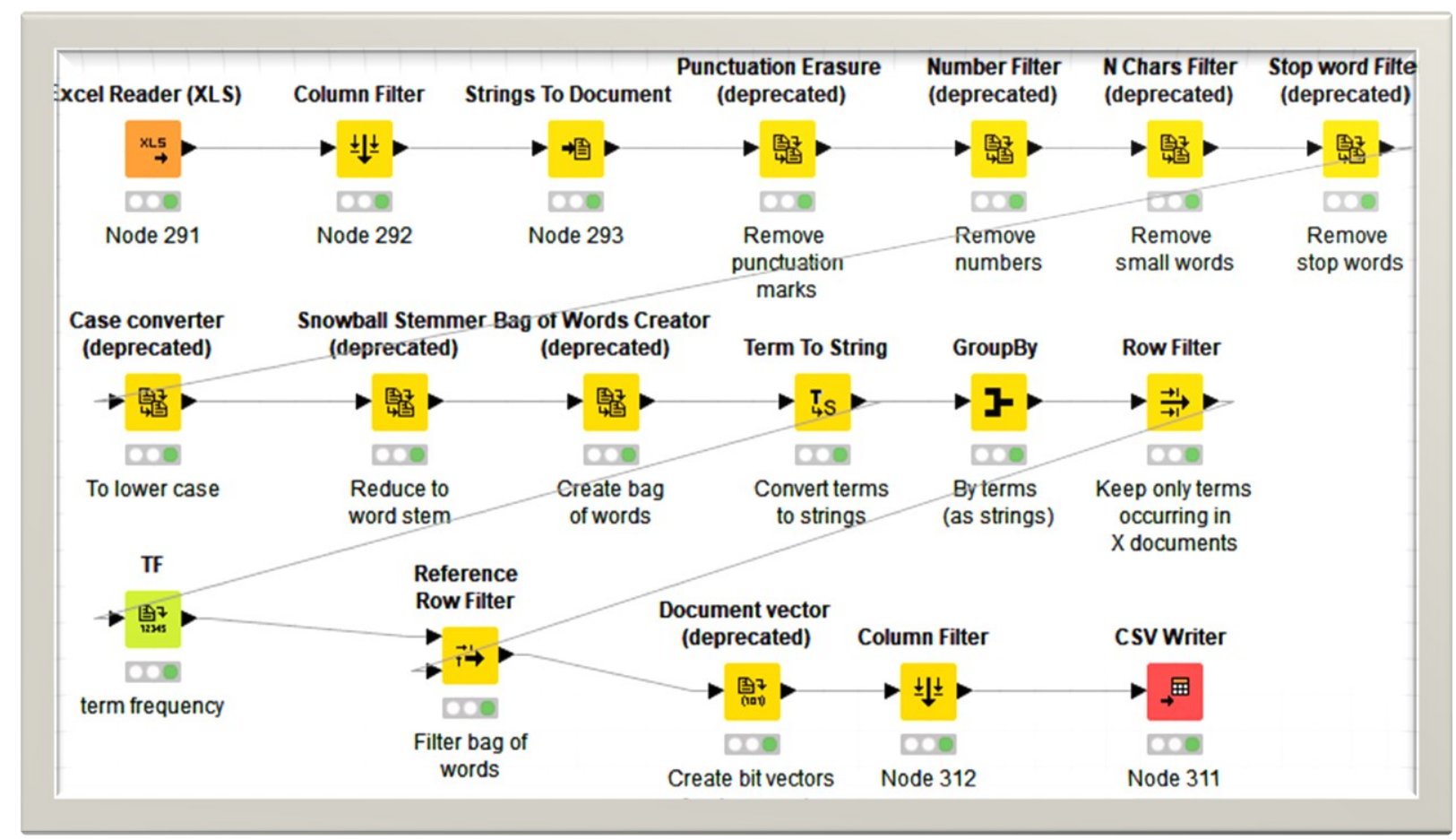

Figure 4. Data cleansing process in this study

\subsection{Data Analysis}

Text mining technique was used in the analysis of the data obtained from the research. Text mining means the study of data that aims to obtain structured data in an unstructured text which regards the text as a source of data (Şeker, 2014, Ergün, 2017). It is also known as text data mining or knowledge discovery from of text database since it extracts useful information from the text. Text mining refers to a variation of an area called data mining, which attempts to find an interesting pattern in big databases. The text-mining tool would extract a particular document and pre-process it by checking the format and character sets. Lastly, the document would go through a phase of text analysis. Text analysis refers to a semantic analysis to derive high-quality information from text. A myriad of text analysis techniques are available; basing on the goal of the organization combinations of techniques could be used ( Gaikwad, S.V., Chaugule, A.,\& Patil, P., 2014).

Text mining refers to a technique that helps the analysis and definition of information and meaningful extraction from the texts. The purpose is to obtain the information of high quality.

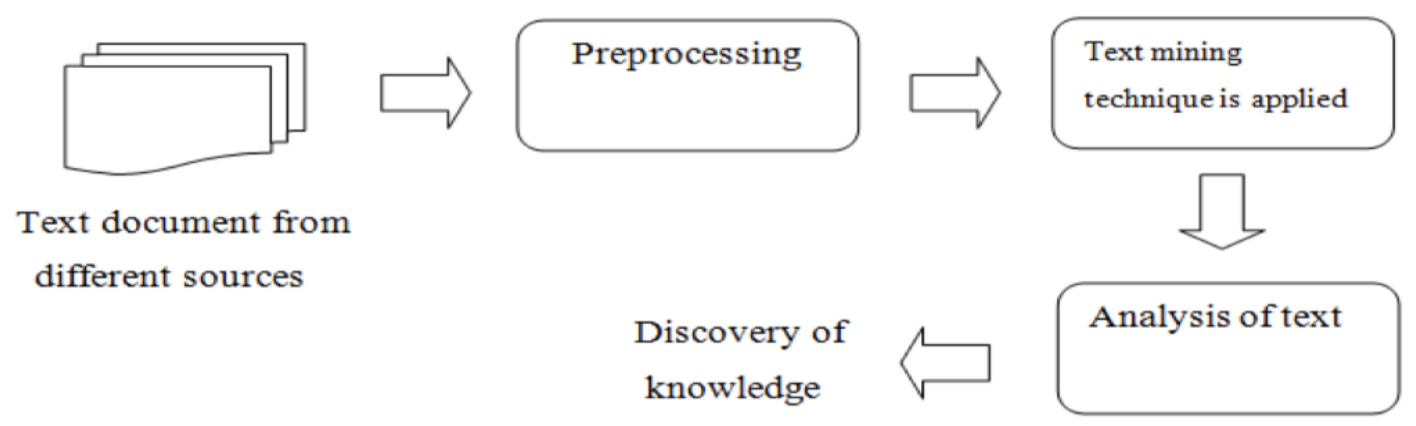

Figure 5. Text mining process (Gaikwad, S.V., Chaugule, A.,\& Patil, P., 2014)

Typical text mining involves text categorization, text clustering, extraction of concept/entity document summarization, production of granular taxonomy and entity-relationship modelling. Text mining has often been utilized for the content analysis of discussion forums, conversations, web pages, documents, and so on (Romero and Ventura, 2012).

Being one of the data mining models, association rule mining was used to define the relationship among the words shared about education on Twitter. The purpose of association rule mining as one of the definitive data mining models is 


\section{The Analysis Of Opinions About Teaching Profession On Twitter Through Text Mining Seda Gündüzalp \& Gönül Şener}

to find association relationship and determine the size of the relationship among them (Akpinar, 2000; Thabtah et al., 2006; Ay \& Çil, 2010; Güngör et al., 2013; Yurdakul, 2015; Uzun, 2016).

As one of the association rule mining algorithms, the Apriori algorithm has been used in this paper. Apriori algorithm is the most commonly known and used association rule mining algorithm, developed by Agrawal and Srikant in 1994 (Han \& Kamber, 2001). The algorithm aims to find out the connection between the lines in the database. The algorithm uses a bottom up approach and after examining only one element at every turn, it attempts to discover the relationship between this element and the others (Şeker, 2011).

As confidence measures, the power of the obtained association rule mining, support shows how often this rule takes place in the database (as cited in Groth, 1999i Bilen et al., 2012). If the reliability value is one hundred percent, the rules are known as definite rules and they are accurate in all data analysis. In this paper, it is determined that the minimum reliability value is 0.80 ; the minimum support value is 0.1 and the significance degree is 0.05 .

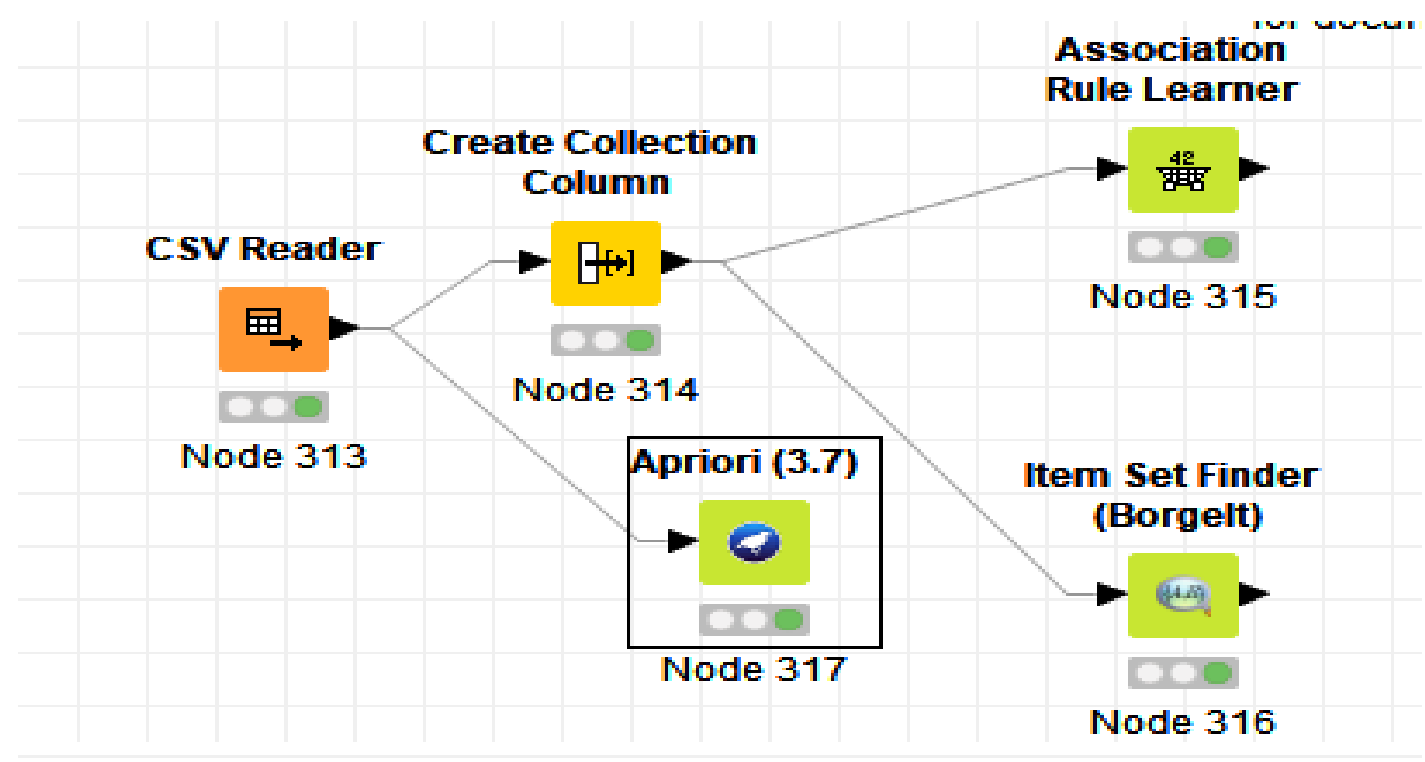

Figure 6 . The process of analysis of data association rule mining

\section{Results}

In the result of the analysis to find the answer to the question 'Which one of them is the most retweeted?', the first research question, the findings are shown as follows. The most retweeted three tweets are:

1. Vehemently condemn the indifference of Ekşisözlük towards the teaching profession. The educators have overcome this presumptuous and immoral website. Now, it is the turn of the authorities. Know your place.

2. Teacher is mother, father, sister, and friend. Çağlar teacher is the one who dances with her disabled student in joy on children's day. The teaching profession is the most conscientious. Respectfully, lovely teacher.

3. Teaching profession is a holy job. To undervalue the teachers whom we trust our future is impertinent. If you tell them to make a speech for 15 minutes, the people who will make a mistaken deal are obsessed with the vacation of the teacher.

On analysing the tweets in the data collection span for analysis, it could be understood that the messages that would harm the value and divinity of the teaching profession in social media platform were shared and this would be the main topic on Twitter and the most retweeted was this tweet as a condemn message by Twitter users. It was seen that starting with the sentence 'Teacher is mother, father, sister, and friend....' and the tweet about a video in which a teacher called Çağlar dances with a disabled student with a wheeled chair was mostly shared was the secondly retweeted. Upon analysing the tweets, it could be seen that the most retweeted third one is that of sharing of reaction against the negatively written about their holiday period.

After the analysis to find the answer to the question 'Which one of them is the most liked tweet?', the second research question, the findings are shown as follows.

Three most liked tweets: 


\section{The Analysis Of Opinions About Teaching Profession On Twitter Through Text Mining}

Seda Gündüzalp \& Gönül Şener

1. Teaching profession is a holy job. To undervalue the teachers whom we trust our future is impertinent. If you tell them to make a speech for 15 minutes, the people who will make a mistaken deal obsess about the vocation of the teacher.

2. Imagine it: You study in high school and your teacher is Jean-Paul Sartre. Jean-Paul Sartre taught and gave philosophy courses between 1931 and 1945 years in several high schools such as Le Havre, Laon, and Paris.

3. The salary of a paid teacher should be increased. To have one-third of the salaries of their colleagues who have the same time, same class and same courses is not a true technique and they should solve it.

On analysing the most liked tweet, it was seen that it is the same as the previous most retweeted one. The second most liked tweet is the sharing starting with the sentence 'Imagine it: You study in high school and your teacher is Jean-Paul Sartre.' It is seen that the third most liked tweet is about paid teaching. This subject is often a trending topic based on the problems of paid teaching. As a consequence of the analysis to find the answer to the third research question of research questions 'Which words are frequently collocated in tweets including teaching and how is the relationship between the teaching and the words?' The findings are shown in Table 1.

Table 1 . The analysis of association rule mining of tweets including teaching word

\begin{tabular}{lc}
\hline Rules & Significance Degree \\
\hline Holy, profession, teaching profession & 0.93 \\
Interview, contracted, teaching profession & 0.92 \\
Teaching profession, ziyaselcuk, teaching & 0.92 \\
Student, teaching, teaching profession & 0.91 \\
Teaching profession, waiting, appointment, assignment & 0.90 \\
Public personnel selection exam, teaching profession. & 0.90 \\
Teaching profession, paid & 0.90 \\
Vacation, teaching profession & 0.90 \\
Liked, profession, teaching profession & 0.90 \\
Interview, teaching profession & 0.89 \\
Paid, ziyaselcuk & 0.88 \\
Government, guarantee, teaching profession & 0.88 \\
Exam, teaching profession & 0.87 \\
Profession, teaching profession & 0.85 \\
Teaching profession, profession, Law & 0.85 \\
Festival, teaching profession & 0.85 \\
\hline
\end{tabular}

When analysing Table 1, it was observed that the 'Holy, profession, teaching' are frequently collocated. It is an expected finding that the most collocated words in tweets about teaching accepted as a holy profession. As a result of analysis, it could be concluded that the words taking place on the on the top lines and referring to the problems of teaching such as 'Interview, contracted, teaching profession', 'Teaching profession, ziyaselcuk, teaching', 'Vacation, teaching profession', 'Teaching profession, waiting, appointment, assignment', 'Public personnel selection exam, teaching profession', 'Teaching profession, paid', 'Interview, teaching profession', 'Paid, ziyaselcuk', 'Government, guarantee, teaching profession', 'exam, teaching profession' are collocated. Furthermore, it could be deduced from the findings that the words including love, respect and divinity such as 'Student, teaching, teaching profession', 'Liked, profession, teaching', 'Festival, teaching profession', 'Profession, teaching profession' are collocated. The collocation of 'Teaching profession, profession and law' has shown that the teaching profession law planned to be enacted by National Education Ministry is the main topic on Twitter.

Examples of tweets:

- Teaching is a holy profession. Never involve outrage and comparison. You must have a value judgement.

- We are hundreds of eliminated in contracted teaching interview. We did not deserve this elimination. We are suffered.

- @Ziyaselcuk (The Minister of Education) Contracted teaching harmed the profession of teaching. We endeavored [sic], studied to carry out our dreams. We are far away our hometown.

- My student started working in book fair. He said that I reserved book for you. Really, teaching is such a nice job.

- The university diploma does not guarantee. When I search for Public Personnel Selection Exam about employing physics teacher, I realize that it mentions 132 teachers. You imagine it that department is teaching. Supply and demand.

- What did I do? I worked hard for many years as a paid teacher. It should be responded to my labor [sic].

- I laughed 48 times differently to the same joke to 48 children. Nobody will say that you are making summer holiday. 


\section{The Analysis Of Opinions About Teaching Profession On Twitter Through Text Mining}

Seda Gündüzalp \& Gönül Şener

- Teaching is LOVE:)The hopes and sorrows you HUG SMILE, expected joys are your beautiful lovers.

- Interview should not be made. Teaching, medical, engineering, agriculture and environment, nowhere.

- My dear municipal, if there is the discrimination of teachers such as paid, contracted and staffed, the people see teachers worthless, paid teaching should be abolished, the bad perception should be erased.

- Teaching is different love for special needs kids, to be under state guarantee is a right.

- If I confirm in 20 different sources a mistake a teacher taught, I always have a suspicion. I do it like my teacher teaches me during the exam.

- The most respectful job is this. However[,] it is not in Turkey.

- We hope that teaching profession law pass into law in a short time and the appointment of teachers is made as staffed.

- Not eliminate us to do our favorite [sic] teaching profession. We will live double festivals.

\section{Discussion, conclusion, recommendations}

As a result of the analysis, it was observed that the shared tweets were often related to the current problems about education, and Twitter was used as a platform by the individuals to explain their problems. It was significantly found that most of the tweets focussed on contracted teaching, the positions of appointment, public personnel selection exam and the system of exams, issues about assignation, paid teaching and interview issues and there are a great number of reaction tweets against negative evaluation, about the vacation of teacher and particularly against the situations just like damaging the sanctity the teaching profession and these tweets take place in the category the most retweeted. Another significant finding is that Teaching Profession Law including the currents trends is enacted and the users about this law set the agenda frequently.

There have been a few studies in which sharing on Twitter were utilized as data set in the education area. Several studies have been shown briefly as follows: Veletsianos (2012) in his study, qualitatively analysed tweets 45 academicians posted, to reach the dominant topics defining online social networking practices. The researcher determined that the academicians sharing on Twitter shared information and sources of professional practices, media, classes students and had social comments, attempted to connect another one. These findings help to understand the newly arisen practice of scientific participation in online networks.

Bista (2015) conducted a study in which the researcher analysed the uses of Twitter as an educational device. The researcher determined that Twitter has provided area and possibilities to carry out academic activities as an academic pedagogic tool to participants and they also used Twitter to take course information, ask mentors the questions, update course appointment and share useful information with mentors and classmates rather than course book Munoz, PellegriniLafont and Cramer (2014) carried out a study about Twitter sharing of students and they concluded that the students shared their feelings and experiences in text content, used this platform to collaborative learning and to interrelate with the class. McArthur and Bostedo Conway (2012) determined that there has been a significant positive relationship between learning and the use of Twitter.

Along with the fact that every kind of opinion shared in social media in the digital age, the large data source on digital platforms has become an interesting area for researchers. For this reason, it is possible to research many subjects in digital environments. With this research, it is suggested to conduct analysis on social media platforms with other data mining techniques on the same subject or different subjects, to analyze the shares of institutions, and to examine the sharing of the Ministry of Education.

\section{References}

Adams, B., Raes, A., Montrieux, H., \& Schellens, T. (2018). "Pedagogical tweeting" in higher education: boon or bane? International Journal of Educational Technology in Higher Education, 15(1), 19.

Akpınar, H. (2000). Veri Tabanlarında Bilgi Keşfi ve Veri Madenciliği. İ.Ü. İşletme Fakültesi Dergisi, 29, 1-22.

Aspden, E.J. \& Thorpe, L.P. (2009). "Where Do You Learn?": Tweeting to İnform Learning Space Development. Educause Quarterly, 32(1).

Ay, D. ve Çil, İ. (2010). Migros Türk A.Ş. de Birliktelik Kurallarının Yerleşim Düzeni Planlamada Kullanılması. Endüstri Mühendisliği Dergisi, 21(2), 14-29.

Aydın, S. (2014). Twitter As An Educational Environment. Turkish Online Journal of Distance Education TOJDE, Volume: 15(1), 1-21 


\section{The Analysis Of Opinions About Teaching Profession On Twitter Through Text Mining}

Seda Gündüzalp \& Gönül Şener

Bicen, H., \& Cavus, N. (2012). Twitter usage habits of undergraduate students. Procedia-Social and Behavioral Sciences, 46, 335-339.

Bilen, Ö., Ökten, A. ve Gökalp, F. (2012). İstanbul'da Suçun Kentsel Sorun Algısındaki Yerinin Birliktelik Kuralları ile İncelenmesi. MEGARON, 7(1), 26-35.

Bista, K. (2015). İs Twitter an effective pedagogical tool in higher education? Perspectives of education graduate students. Journal of the Scholarship of Teaching and Learning, 15(2), 83-102.

Chawinga, W. D. (2016). Teaching and learning 24/7 using Twitter in a university classroom: Experiences from a developing country. E-learning and Digital Media, 13(1-2), (4).

Ergün, M. (2017). Usıng The Technıques Of Data Mınıng And Text Mınıng In Educatıonal Research. Electronıc Journal Of Education Sclences, 6(12), (180-189).

Gaikwad, S. V., Chaugule, A., \& Patil, P. (2014). Text mining methods and techniques. International Journal of Computer Applications, 85(17).

Güngör E., Yalçın N. ve Yurtay N. (2013, Ocak). Apriori Algoritması ile Teknik Seçmeli Ders Seçim Analizi. Akademik Bilişim Konferans1, Antalya.

Han, J. and Kamber, M. (2001). Data Mining: Concept and Techniques. CA, Academic Press.

https://blog.twitter.com/official/en us/a/2011/numbers.html

Internet Live Stats, 10 Haziran 2019'erişilmiştir from mwww.internetlivestats.com (2019)

Junco, R., Heiberger, G. \& Loken, E. (2011). The effect of Twitter on college student engagement and grades. Journal of Computer Assisted Learning, 27, 119-132.

Kaplan, A. M., \& Haenlein, M. (2010). Users of the world, unite! The challenges and opportunities of Social Media. Business horizons, 53(1), 59-68.

Kaplan, İ. (2017). Üniversite ögrencisi sosyal medya kullanıcılarının mahremiyet algısı. Yüksek Lisans Tezi, Anadolu Üniversitesi.

Kassens-Noor, E. (2012). Twitter as a teaching practice to enhance active and informal learning in higher education: The case of sustainable tweets. Active Learning in Higher Education, 13(9), 8-21.

Lin, M. F., Hoffman, E. S., Borengasser, C. (2013). İs social media too social for class? A case study of Twitter use. TechTrends, 5 (2), 39-48.

Luttrell, R. (2012). Social networking sites in the public relations classroom: A mixed methods analysis of undergraduate learning outcomes using wordpress, facebook, and twitter (unpublished doctoral dissertation). California Institute of Integral Studies, San Francisco, CA. UMİ No. 3539719

McArthur, J. A., \& Bostedo Conway, K. (2012). Exploring the relationship between student instructor interaction on Twitter and student perception of teacher behaviors. International Journal of Teaching and Learning in Higher Education, 24 (3), 286-292

Meral, M. and Diri, B. (2014). Sentiment analysis on Twitter. 2014 22nd Signal Processing and Communications Applications Conference (SIUU), Trabzon, pp. 690-693.

Shehu, H. A. (2019). Kutupsallı sözlüğü ve yapay zeka yardımı ile Türkçe twitter verileri üzerinde duygu analizi. Yüksek Lisans Tezi, Pamukkale Üniversitesi Fen Bilimleri Enstitüsü.

Munoz, L. R., Pellegrini-Lafont, C., \& Cramer, E. (2014). Using Social Media in Teacher Preparation Programs: Twitter as a Means to Create Social Presence. Penn GSE Perspectives on Urban Education, 11(2), 57-69.

Nagle, J. (2018). Twitter, cyber-violence, and the need for a critical social media literacy in teacher education: A review of the literature. Teaching and Teacher Education, 76, 86-94.

Odabaşı, H. F., Mısırlı, Ö., Günüç, S., Timar, Z. Ş., Ersoy, M., Seçil, S. O. M., ... \& Osman, E. R. O. L. (2012). Eğitim için yeni bir ortam: Twitter. Anadolu Üniversitesi Ĕgitim Bilimleri Enstitüsü Dergisi, 2(1).

Pourebrahim, N., Sultana, S., Thill, J. C., \& Mohanty, S. (2018). Enhancing trip distribution prediction with Twitter data: comparison of neural network and gravity models. In Proceedings of the 2nd ACM SIGSPATIAL International Workshop on AI for Geographic Knowledge Discovery (pp. 5-8). ACM.

Prestridge, S. (2014). A focus on students' use of Twitter-their interactions with each other, content and interface. Active Learning in Higher Education, 15(2), 101-115.

Romero, C. and Ventura S. (2012). Data mining in education. WiREs Data Mining and Knowledge Discovery, vol. 3, pp. $12-27$

Sanchez MJC, Hermoso R, Iñiguez D, Paño-Pardo, J.R., Bandres MA, Martinez MPL, (2019). Qualitatıve And Quantitatıve Evaluation Of The Use Of Twitter As A Tool Of Antımıcrobial Stewardshıp, International Journal of Medical Informatics, doi: https://doi.org/10.1016/j.ijmedinf.2019.103955

Şeker, S.E. (2011). Apriori Algoritmast. http:// bilgisaya rkavramlari .sadievrenseker . com/2011/09/07/apriorialgoritmasi/. (09.06.2016 tarihinde erişilmiştir).

Şeker, S.E. (2014). Metin Madenciliği (Text Mining), http://bilgisayarkavramlari.sadievrenseker.com/2014/06/15/metinmadenciligi-text-mining/

Tang, Y., \& Hew, K. F. (2017). Using Twitter for education: Beneficial or simply a waste of time?. Computers \& Education, 106, 97-118.

Thabtah, F., Cowling, P. And Hammoud, S. (2006). İmproving Rule Sorting, Predictive Accuracy and Training Time in Associative Classification. Expert Systems with Applications, 31, 414-426,

Research on Education and Media. Vol. 12, N. 1, Year 2020 - ISSN: 2037-0830 
Tuncer, D. Ç. T. ve Çetintaş, D. Bir Sosyal Ağdan Alınan Verilerin Anlamsal Kutuplandırılması. Anatolian ScienceBilgisayar Bilimleri Dergisi, 1-6.

Tur, G. \& Marn, V. (2015). Enhancing learning with the social media: student teachers' perceptions on Twitter in a debate activity. Journal of New Approaches in Educational Research (NAER Journal), 4(1), 46-53.

Uzun, E. (2016). Association Rules (Birliktelik Kurallarl). http://bilgmuh.nku.edu.tr/erdincuzun/post/association-rulesbirliktelik-kurallari. (08.06.2016 tarihinde erişilmiştir).

Veletsianos, G. (2012). Higher education scholars' participation and practices on Twitter. Journal of Computer Assisted Learning, 38, 336-349.

Vooren, C. V., \& Bess, C.(2013). Teacher tweets improve achievement for eight grade science students. Systemic, Cybernetics, and Informatics, 2(1), 33-36.

Vural, Z., \& Bat, M. (2010). Yeni Bir İletişim Ortami Olarak Sosyal Medya: Ege Üniversitesi İletişim Fakültesine Yönelik Bir Araştirma. Journal of Yasar University, 5(20).

Wright, N. (2010). Twittering in teacher education: Reflecting on practicum experiences. Open Learning, 25(3), 259265.

Yakın, İ., \& Tinmaz, H. (2013). Using Twitter as an instructional tool: A case study in higher education. TOJET: The Turkish Online Journal of Educational Technology, 12(4).

Yıldırım, A. \& Şimşek, H. (2011). Sosyal bilimlerde nitel araştırma yöntemleri. (8. baskı). Ankara: Seçkin Yayıncılık.

Yurdakul, S. (2015). Veri Madenciliği ile Lise Öğrenci Performanslarının Değerlendirilmesi. Yayımlanmamış yüksek lisans tezi, Kırıkkale Üniversitesi Fen Bilimleri Enstitüsü, Kırıkkale. 